\title{
PROTEOLYTIC ACTIVITY OF IgGs FROM BLOOD SERUM OF WISTAR RATS AT EXPERIMENTAL RHEUMATOID ARTHRITIS
}

\author{
Yu. Ya. KIT', S. L. MYRONOVSKY', I. I. KRIL'2, A. M. HAVRYLYUK', \\ V. V. CHOP'YAK', R. S. STOIKA \\ ${ }^{1}$ Institute of Cell Biology, National Academy of Sciences of Ukraine, Lviv; \\ ${ }^{2}$ Danylo Halytsky Lviv National Medical University, Ukraine; \\ ${ }^{3}$ Ivan Franko National University of Lviv, Ukraine; \\ e-mail: kit@cellbiol.lviv.ua
}

The aim of this work was to study the proteolytic activity of IgGs purified from blood serum of Wistar rats at experimental rheumatoid arthritis (ERA) induced by an injection of bovine collagen of type II. Twenty rats were immunized with a preparation of bovine collagen II (Sigma-Aldrich, USA) in the presence of complete Freund's adjuvant. ERA development was determined by inflammation in limbs of treated animals. IgG preparations were isolated from blood serum of immunized and non-immunized animals by precipitation of antibodies with 33\% ammonium sulfate followed by chromatography on the Protein G-Sepharose column. Human histone H1, bovine collagen II, calf thymus histones, myelin basic protein (MBP), bovine serum albumin (BSA), and bovine casein were used as substrates of the proteolytic activity of IgGs. It was found that IgG preparations from blood serum of rats with ERA were capable of cleaving histone H1 and MBP, however, they were catalytically inactive towards collagen II, casein, BSA, and core histones. IgGs from blood serum of non-immunized rats were proteolytically inactive towards all used protein substrates. Thus, we demonstrated that immunization of rats with bovine collagen II induced IgG-antibodies possessing the proteolytic activity towards histone $H 1$ and MBP. This activity might be associated with the development of inflammatory processes in the immunized rats.

Key words: antibodies, proteolytic activity, substrate specificity, rheumatoid arthritis, Wistar rats, bovine collagen II, immunization.

I nteraction of antibodies with antigens may cause not only binding, but also a destruction or modification of these antigens. Some proteins, nucleic acids and oligosaccharides play a role of substrates during catalysis with participation of antibodies. Antibodies possessing the catalytic activity are named abzymes [1-4], and abzymes with the proteolytic activity are named protabzymes $[2,4]$. The protabzymes of IgG sub-class that are capable of hydrolyzing intestinal vasoactive peptide (VIP), have been detected in blood serum of asthma patients [5]. It was found that destruction of autoantigens by the protabzymes is tightly associated with development of some autoimmune diseases. For instance, in patients with the acute allergic thyroiditis, the anti-thyreoglobulin auto-ABs are capable of hy-

drolyzing thyreoglobulin [6], while in patients with autoimmune myocarditis, the auto-Abs are capable of hydrolyzing myosin [7]. In patients with multiple sclerosis, the auto-ABs were capable of hydrolyzing myelin basic protein (MBP) [8]. The proteolytically active $A B s$ have been also detected in blood serum of patients with some cancer and inheritable diseases $[9,10]$, as well as in blood serum of some clinically healthy people [3, 11-14]. It was shown that in norm protabzymes may participate in destruction and removal from the organism of some pathogenic proteins involved in virus infections [3] and neurodegenerative diseases [11-13]. These data demonstrate that, depending on substrate specificity, protabzymes may possess the pathogenic or defending function in human organism.

\footnotetext{
Abbreviations used in the work: ABs- antibodies, auto-ABs - autologic antibodies, SLE - systematic lupus erythematosus, RA - rheumatoid arthritis, ERA - experimental rheumatoid arthritis, MBP - myelin basic protein.
} 
We have found for the first time that IgG-protabzymes capable of hydrolyzing histone $\mathrm{H} 1$ are present in blood serum of patients with multiple sclerosis, systematic lupus erythematosus (SLE), multiple myeloma, as well as in colostrum of healthy women $[11,15,16]$. These protabzymes have not been detected in blood serum of healthy donors. Comparative studies of blood serum of SLE patients and colostrum of healthy mothers have shown that IgG- and sIgA-protabzymes with affinity for histone $\mathrm{H} 1$ are capable of cleaving two different substrates - histone H1 and MBP [17, 18]. Their level in blood serum positively correlated with heaviness of multiple sclerosis $[19,20]$. We suggested that the appearance of IgG-protabzymes in blood serum may be caused by an inflammatory process linked with development of the autoimmune diseases. To check this presumption, experimental model of the rheumatoid arthritis (RA) has been used. The inflammatory processes in joints and subtend tissues are major features of the RA. [21]. The development of experimental RA-similar pathology may be induced in rats by the injection of complete Freund adjuvant (adjuvant arthritis) [22], or bovine collagen II type in a complex with incomplete Freund adjuvant (collageninduced arthritis) [22, 23]. In this work, we aimed at a search of proteolytically active IgG in blood serum of rats with experimental collagen-induced arthritis.

\section{Materials and Methods}

Blood was obtained from 20 immunized and 20 non-immunized (control) Wistar rats of different sex, aged 2 months, weighing 160-200 g. Animals were treated in compliance with the Council of Europe Convention on protection of vertebrate animals which are used for scientific purposes.

Immunization of rats. Immunization was performed according to [22]. Rats were injected once with $400 \mu \mathrm{g}$ of bovine collagen II type (Sigma-Aldrich) in $15 \mathrm{mM}$ acetic acid in the incomplete Freund adjuvant (Calbiochem-Behring) into right hind leg. The animals were observed for 36 days after the immunization, and arthritis development was determined by monitoring inflammation in tissue of hind legs [22-24]. Animals were decapitated in order to obtain blood of the immunized and control animals.

Purification of IgGs. IgGs were purified from blood serum of rats according to [16]. To do that, $1 \mathrm{ml}$ of rat blood serum was centrifuged (5,000 g, 5 min). Total ABs were precipitated with $33 \%$ $\left(\mathrm{NH}_{4}\right)_{2} \mathrm{SO}_{4}$, followed by dialysis against TBS buffer
(140 mM NaCl, 20 mM Tris-HCl, pH 7.5) for $18 \mathrm{~h}$. IgGs were purified by the affinity chromatography on a column filled with protein G-sepharose (SigmaAldrich). IgGs were eluted from the column with $0.1 \mathrm{M}$ glycine- $\mathrm{HCl}$ buffer ( $\mathrm{pH}$ 2.6) and neutralized with $1.5 \mathrm{M}$ Tris-HCl ( $\mathrm{pH} 8.8$ ). The obtained IgG preparations were dialyzed against the TBS for $18 \mathrm{~h}$. Protein concentration in the IgG-preparations was measured by means of NanoDrop ND-1000 spectrophotometer (NanoDrop, USA).

Assessment of proteolytic activity of IgGs. Bovine collagen II, bovine myelin basic protein, BSA were purchased from (Sigma, USA), chicken egg's lysozyme (Reanal, Hungary), bovine milk casein, linker histone $\mathrm{H1}$, and total histones of calf thymus (Axora, Germany). They were used as substrates of the proteolytic reaction. The reaction was conducted for $3 \mathrm{~h}$ at $37^{\circ} \mathrm{C}$ in $20 \mu \mathrm{l}$ of the incubation mixture containing $20 \mathrm{mM}$ of Tris- $\mathrm{HCl}$ (pH 7.5), 1-3 $\mu \mathrm{g}$ of antibodies, and 5-10 $\mu \mathrm{g}$ of protein substrates. The reaction was stopped by addition to the mixture of $5 \mu \mathrm{l}$ of denaturation buffer $(0.2 \mathrm{M}$ of Tris- $\mathrm{HCl}(\mathrm{pH} 6.8)$, $4 \%$ DSNa, 8\% 2-mercaptoethanol, and 20\% glycerol). The reaction mixture was heated at $100{ }^{\circ} \mathrm{C}$ for $3 \mathrm{~min}$, and products of hydrolysis were separated by electrophorese in $15 \%$ PAAG in the presence of DSNa [25]. Proteins on gels were stained with Coomassie R-250.

\section{Results and Discussion}

Inflammation of tissues in the hind legs of immunized rats, but not in control animals, were observed (Fig. 1). IgG isolated from blood serum of both immunized and control animals was checked for the presence of the proteolytic activity towards possible protein antigens. Typical results of lacking proteolytic activity towards bovine collagen II of the IgGs purified from blood serum of the immunized and control rats are presented on Fig. 2, A. On the other hand, IgGs purified from rats with ERA were capable of cleaving histone $\mathrm{H} 1$ contained in the preparation of total calf thymus histones (Fig. 2, B, lane 2). IgG isolated from the non-immunized animals was lacking such activity (Fig. 2, B, lane 1). The destruction of core histones by the IgG of immunized, as well as control animals, was not detected.

At the next step, IgG-preparations capable of cleaving histone $\mathrm{H} 1$ were tested for hydrolyzing activity towards other protein substrates. It was found that IgGs from blood serum of rats with ERA cleaved histone H1 (Fig. 3, lanes 4, 4', 5, 5’). The 
$A$

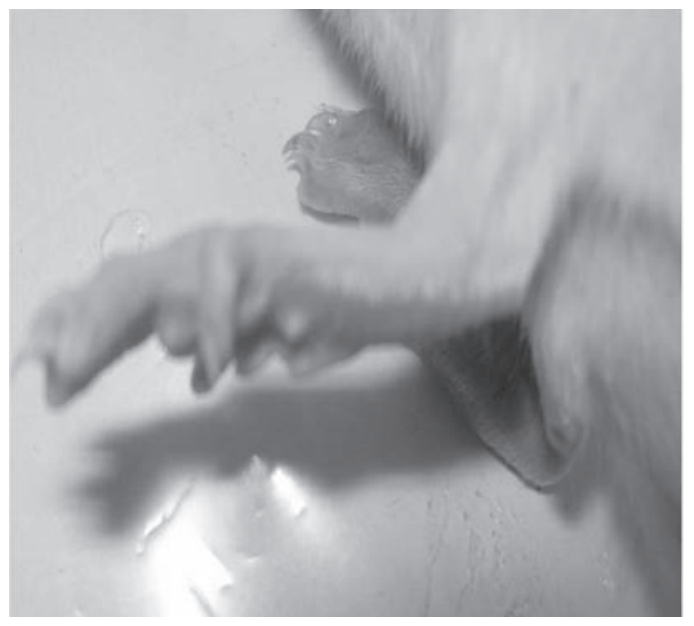

B

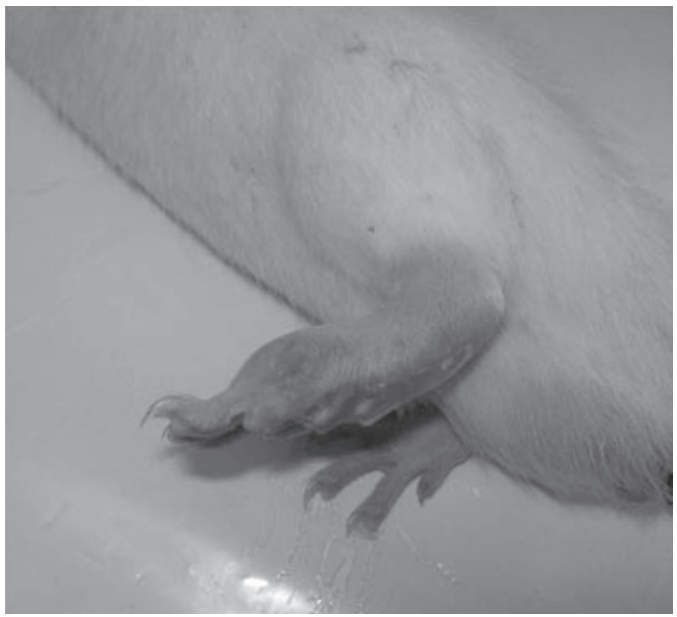

Fig. 1. Inflammation of tissues in the hind legs of Wistar rats immunized with bovine collagen II. A-legs under control (non-immunized animal), B - legs of animal on the $36^{\text {th }}$ day after immunization

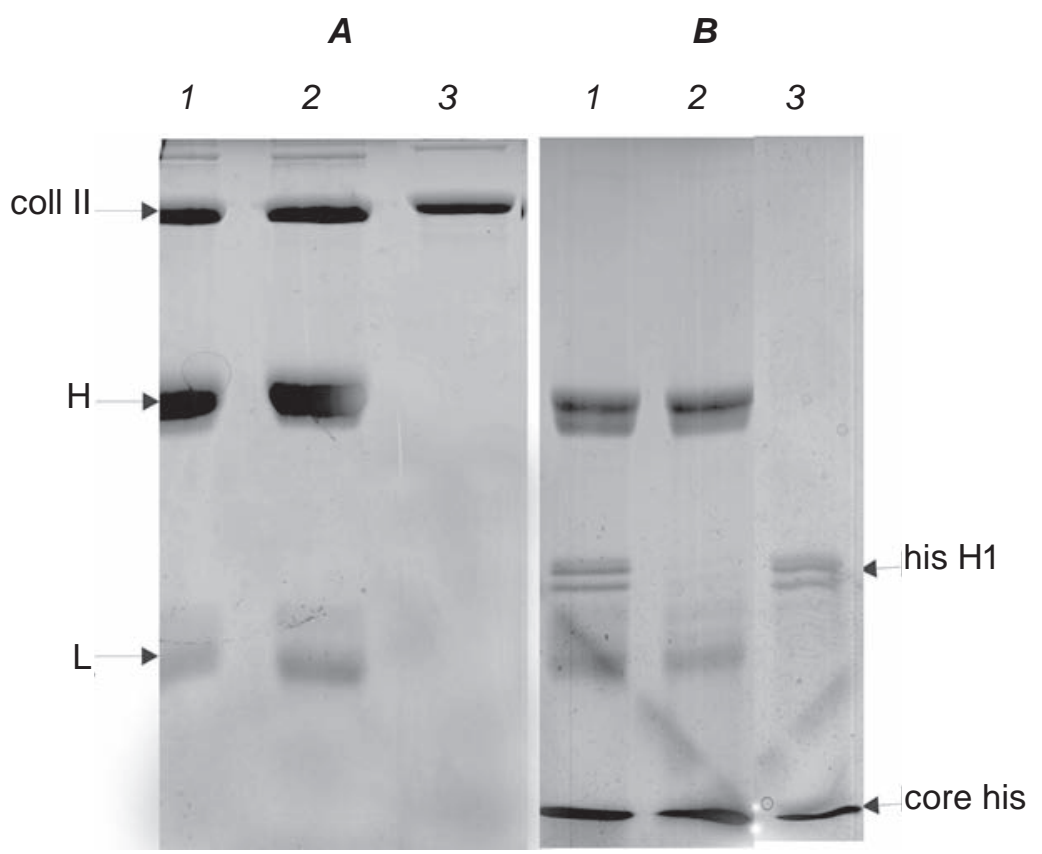

Fig. 2. Elecrtophoretic pattern of IgGs possessing proteolytic activity and purified from blood serum of immunized and non-immunized rats towards collagen II (A) and histones of calf thymus (B). Lane 1 - nonimmunized animals. Lane 2 - animals 36 days after immunization. Lane 3 - control (collagen II (A) and total histones (B) without addition of IgGs). On the left, the positions of collagen II on the gel (coll II), heavy (H) and light (L) IgG chains are shown. On the right, the position of linker histone H1 and core histones of calf thymus (core his) are shown

amount of peptide products of the proteolytic reaction suggests that the efficiency of hydrolysis of MBP was much higher than the hydrolysis of histone H1. At the same time, the IgGs under study were inactive towards bovine serum albumin and casein (Fig. 3, lanes 2, 2', 3, 3’). Similar substrate specific- ity towards hydrolysis of histone $\mathrm{H} 1$ and MBP was demonstrated for the protabzymes which we earlier purified from blood serum of systemic lupus erythematosis patients [16-20].

Recently, it was shown that IgG- and IgM-antibodies present in blood serum of RA patients, are 


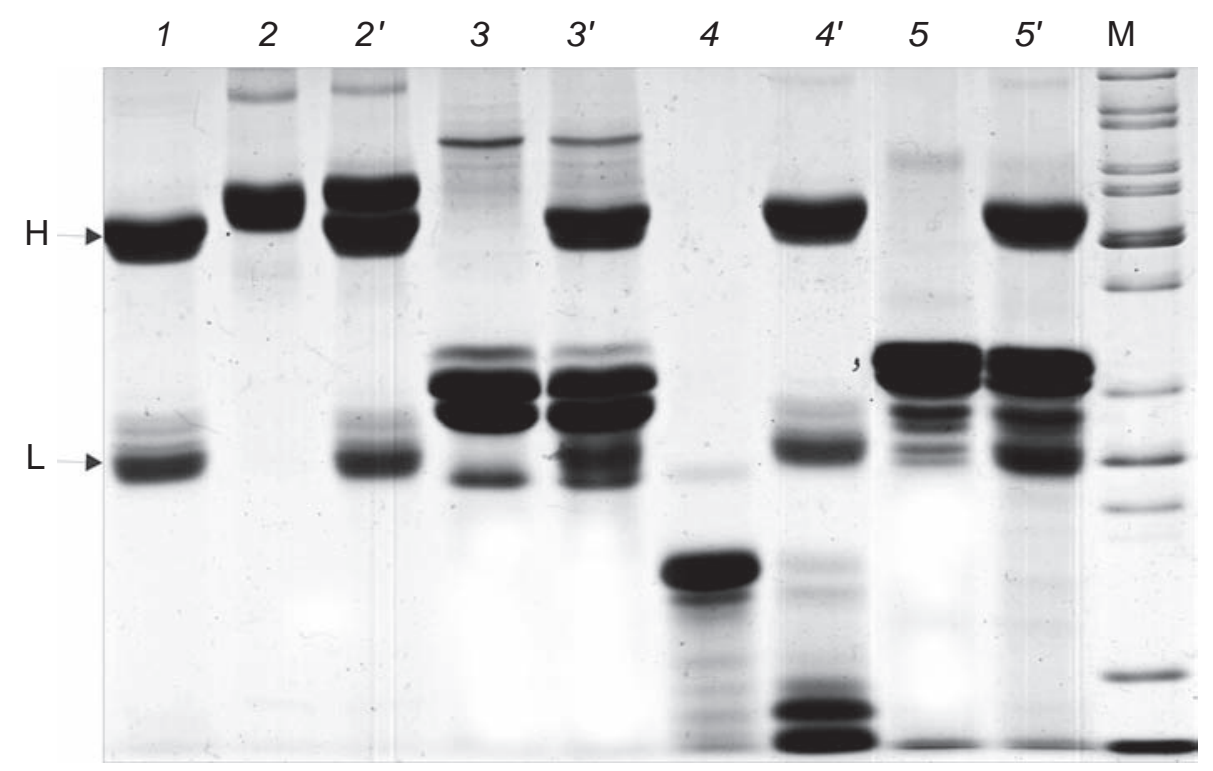

Fig. 3. Electrophoretic pattern of IgGs (lane 1) possessing of proteolytic activity and purified from blood serum of the immunized rats toward: BSA (lanes 2, 2'), bovine casein (lanes 3, 3'), bovine myelin basic protein (lanes 4,4'), humane histone H1 (lines 5, 5'). Lanes 2, 3, 4, 5-protein substrates without of addition of IgGs. Lanes 2', 3', 4', 5' - protein substrates after treatment with IgGs. Positions of heavy (H) and light (L) chains of $\operatorname{IgG}$ on the gel are shown on the left. M-markers of the molecular mass of proteins $(150,120,100,85,70$, 50, 40, 30, 25, 20, 15, $10 \mathrm{kDa}$ )

capable of hydrolyzing synthetic Pro-Phe-Arg-4-methyl-cumarinimid peptide [26]. Antibodies possessing similar proteolytic activity have been found in blood serum of sepsis patients [28]. It was detected that increasing of level of protabzymes in blood serum positively correlated with the development of that pathology. The obtained results allow one to suggest that revealed protabzymes possess either positive or negative action in human organism; however, this assumption should be studied additionally.

Summarizing, we have shown that ERA induced by the immunization of rats with bovine collagen type II was accompanied by an appearance of the catalytically active antibodies capable of hydrolyzing histone $\mathrm{H1}$ and MBP in blood serum. That might be connected with the development of inflammatory processes in the immunized animals. Further studies to prove this assumption are in progress.

\section{ПРОТЕОЛІТИЧНА АКТИВНІСТЬ IgG СИРОВАТКИ КРОВІ ЩУРІВ ЛІНІЇ WISTAR 3A ЕКСПЕРИМЕНТАЛЬНОГО РЕВМАТОЇДНОГО АРТРИТУ}

\author{
Ю. Я. Кіт ${ }^{1}$ С. Л. Мироновський \\ I. Й. Кріль², А. М. Гаврилюк², В. В. Чоп'як², \\ P. С. Стойка
}

${ }^{1}$ Інститут біології клітини НАН України, Львів;

${ }^{2}$ Львівський національний медичний університет імені Данила Галицького, Україна;

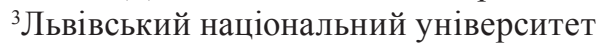
імені Івана Франка, Україна; e-mail: kit@cellbiol.lviv.ua

Метою роботи було дослідити протеолітичну активність $\operatorname{IgG}$ сироватки крові щурів лінії Wistar за експериментального ревматоїдного артриту (ЕРА), індукованого 
колагеном бика II типу. Для цього 20 щурів імунізували препаратом колагену бика II типу (Sigma Aldrich, США) у присутності ад’юванта Фрейнда. Розвиток ЕРА визначали за запаленням кінцівок у піддослідних тварин. Препарати $\operatorname{IgG}$ виділяли із сироватки крові імунізованих i неімунізованих тварин, осадженням антитіл $33 \%$-им розчином сульфату амонію 3 наступною хроматографією на протеїн-G-сефарозній колонці. Як субстрати протеолітичної активності антитіл використовували: колаген бика II типу, гістони тимуса теляти, основний протеїн мієліну (ОПМ), БСА, коров’ячий казеїн. Встановлено, що препарати IgG сироватки крові щурів із ЕРА здатні гідролізувати гістон Н1, ОПМ, але каталітично неактивні щодо колагену II типу, казеїну, БСА та корових гістонів. $\operatorname{IgG}$ сироватки крові неімунізованих щурів не виявляли протеолітичну активність до жодного iз цих протеїнових субстратів. Одержані нами дані вказують на те, що за колагеніндукованого артриту у сироватці крові щурів з'являються IgG-антитіла, які виявляють протеолітичну активність щодо гістону Н1 і ОПМ, що може бути пов'язано із розвитком запальних процесів в імунізованих щурів.

К л юч о в і слов а: антитіла, протеолітична активність, субстратна специфічність, ревматоїдний артрит, щури лінії Wistar, колаген бика II, імунізація.

\section{ПРОТЕОЛИТИЧЕСКАЯ АКТИВНОСТЬ IgG СЫВОРОТКИ КРОВИ КРЫС ЛИНИИ WISTAR ПРИ ЭКСПЕРИМЕНТАЛЬНОМ РЕВМАТОИДНОМ АРТРИТЕ}

\section{Ю. Я. Кит ${ }^{1}$ С. Л. Мироновский \\ И. И. Криль , А. М. Гаврылюк ${ }^{2}$ В. В. Чопяк ${ }^{2}$, P. С. Стойка}

\footnotetext{
${ }^{1}$ Институт биологии клетки НАН Украины, Львов;

${ }^{2}$ Львовский национальный медицинский университет имени Данила Галицкого, Украина;

${ }^{3}$ Львовский национальный университет имени Ивана Франко, Украина; e-mail: kit@cellbiol.lviv.ua
}

Целью работы было исследование протеолитической активности $\operatorname{IgG}$ сыворотки крови крыс линии Wistar при экспериментальном ревматоидном артрите (ЭРА), индуцированном кол- лагеном быка II типа. Для этого 20 крыс иммунизировали препаратом коллагена быка II типа (Sigma-Aldrich, США) в присутствии адъюванта Фрейнда. Развитие ЭРА определяли по воспалению конечностей животных. Препараты IgG выделяли из сыворотки крови иммунизированных и неиммунизированных животных, осаждая антитела 33\%-ым раствором сульфата аммония с последующей хроматографией на протеинG-сефарозной колонке. В качестве субстрата протеолитической активности антител использовали: коллаген быка II типа, гистоны тимуса теленка, основной протеин миелина (ОПМ), БСА, коровий казеин. Установлено, что препараты IgG сыворотки крови крыс с ЭРА способны разрушать гистон Н1 и ОПМ, но каталитически неактивны относительно коллагена II, казеина, БСА и коровых гистонов. IgG сыворотки крови неиммунизированных крыс не обладают протеолитической активностью ни к одному из этих протеиновых субстратов. Полученные данные указывают на то, что при коллагениндуцированном артрите в сыроватке крови крыс появляются $\mathrm{IgG-aнтитела,} \mathrm{протеолитически}$ активные в отношении гистона Н1 и ОПМ. Это может быть связано с развитием воспалительных процессов в организме иммунизированных крыс.

К лючевы е слова: антитела, протеолитическая активность, субстратная специфичность, ревматоидний артрит, крысы линии Wistar, коллаген быка II, иммунизация.

\section{References}

1. Gabibov A. G., Ponomarenko N. A., Tretyak E. B., Paltsev M. A., Suchkov S. V. Catalytic autoantibodies in clinical autoimmunity and modern medicine. Autoimmun. Rev. 2006;5(5):324-330.

2. Belogurov A. Jr., Kozyr, A., Ponomarenko N., Gabibov A. Catalytic antibodies: balansing between Dr. Jekyll and M. Hyde. Bioessays. 2009;26(3):116-167.

3. Planque S., Nishiyama Y., Taguchi H., Salas M., Hanson C., Paul S. Catalytic antibodies to HIV: physiological role and potential clinical utility. Autoimmun. Rev. 2008;7(7):473-479.

4. Wootla B., Lacroix-Desmazes S., Warrington A. E., Bieber A. J., Kaveri S. V., Rodriguez M. Autoantibodies with enzymatic 
properties in human autoimmune diseases. J. Autoimmun. 2011;37(2):1-15.

5. Paul S., Nishiyama Y., Planque S., Taguchi H. Theory of proteolytic antibody occurrence. Immunol. Lett. 2006;103(4):8-16.

6. Li L., Paul S., Tyutyulkova S., Kazatchkine M., Kaveri S. Catalytic activity of anti-thyroglobulin antibodies. J. Immunol. 1995;154(8):3328-3332.

7. Ponomarenko N. A., Durova O. M., Vorobiev I. I., Aleksandrova E. S., Telegin G. B., Chamborant O. G., Sidorik L. L., Suchkov S. V., Alekberova Z. S., Gnuchev N. V., Gabibov A. G. Catalytic antibodies in clinical and experimental pathology: human and mouse models. J. Immunol. Methods. 2002;269(4):197-211.

8. Ponomarenko N. A., Durova O. M., Vorobiev I. I., Belogurov A. A. Jr, Kurkova I. N., Petrenko A. G., Telegin G. B., Suchkov S. V., Kiselev S. L., Lagarkova M. A., Govorun V. M., Serebryakova M. V., Avalle B., Tornatore P., Karavanov A., Morse H. C. 3rd, Thomas D., Friboulet A., Gabibov A.G. Autoantibodies to myelin basic protein catalyze site-specific degradation of their antigen. Proc. Natl. Acad. Sci. USA. 2006;103(1):281-286.

9. Lacroix-Desmazes S., Wootla B., Delignat S., Dasgupta S., Nagaraja V., Kazatchkine M. D., Kaveri S. V. Pathophysiology of catalytic antibodies. Immunol. Lett. 2006;103(1):3-7.

10. Paul S., Nishiyama Y., Planque S., Taguchi H. Theory of proteolytic antibody occurrence. Immunol. Lett. 2006;103(1):8-16.

11. Magorivska I., Bilyy R., Shalay O., Loginsky V., Kit Y., Stoika R. Blood serum immunoglobulins of patients with multiple myeloma are capable of hydrolysing histone H1. Exp. Oncol. 2009;31(2):97-101.

12. Paul S., Nishiyama Y., Planque S., Karle S., Taguchi H., Hanson C., Weksler M.E. Antibodies as defensive enzymes. Springer Semin. Immun. 2005;26(6):485-503.

13. Taguchi H., Planque S., Nishiyama Y., Szabo P., Weksler M. E., Friedland R. P., Paul S. Catalytic antibodies to amyloid beta peptide in defense against Alzheimer disease. Autoimmun. Rev. 2008;7(7):391-397.

14. Paul S., Planque S., Nishiyama Y. Immunological origin and functional properties of catalytic autoantibodies to amyloid beta peptid. J. Clin. Immunol. 2010;30(1):43-49.
15. Kit Y. Y., Starykovych M. A., Richter V. A., Stoika R. S. Detection and characterization of IgG- and sIgA-Abzymes capable of hydrolyzing histone H1. Biochemistry (Mosc). 2008;73(4):950-956.

16. Kit Yu. Ya., Magorivska I. B., Havryliuk A. M., Chop'iak V. V., Bilyy R. O., Stoĭka R. S. Proteolytic activity of $\operatorname{IgG}$ of blood serum of patients with systemic lupus erythematosis. Ukr. Biokhim. Zhurn. 2009;81(3):77-83. (In Ukrainian).

17. Magorivska I. B., Bilyy R. O., Havrylyuk A. M., Chop'yak V. V., Stoika R. S., Kit Y. Y. Antihistone H1 IgGs from blood serum of systemic lupus erythematosus patients are capable of hydrolyzing histone $\mathrm{H} 1$ and myelin basic protein. J. Mol. Recognit. 2010;23(5):495-502.

18. Kit Yu., Starykovych M., Mahorivska I., et al. Novel Serine-Protease Like Catalytic Antibodies with Double Substrate Proteolytic Activity in Human Blood Serum and Colostrums. In. "Serine Proteases: Mechanism, Structure and Evolution". Eds.: Isamu Chiba and Takao Kamio/ Nova Sci. Publ., Inc., Hauppauge - NY. 2012:71-89.

19. Chopyak V., Tolstiak Y., Magoryvska I., Bilyy R., Korniy N., Kit Y., Stoika R. Histone h1/MBP hydrolysing antibodies - novel potential marker in diagnosis of disease severity in systematic lupus erythematosus patients. Health. 2010;2(10):1204-1207.

20. Kit Y., Magorivska I., Chopyak V., Tolstiak Y., Bilyy R., Stoika R. Novel Biological Activities of Autoantibodies as the Potential Markers of Systemic Lupus Erythematosus. In "Systemic Lupus Erythematosus (SLE): Prevalence, Pathophysiology and Prognosis". Eds.: Syuichi Koarada. Nova Sci. Publ., Inc., Hauppauge NY. 2013:101-110.

21. Muñoz L. E., Lauber K., Schiller M., Manfredi A. A., Herrmann M. The role of defective clearance of apoptotic cells in systemic autoimmunity. Nat. Rev. Reumatol. 2010;6(8):280-289.

22. Kakimoto K., Hirofuji T, Koga T. Specificity of anti-type II collagen antibody response in rats. Clin. Exp. Immunol. 1984;57(3):57-62.

23. Leonavičienè L., Bradūnaitè R., Vaitkienè D., Vasiliauskas A., Keturkienė. Anti-inflammatory activity of some potassium salts of N,Ndisubstituted 4-aminoazobenzenesulfonic 
acids in rat adjuvant arthritis. Biologiya. 2008;54(4):290-300.

24. Bendele A. M. Animal models of osteoarthritis. J. Musculoskel. Neuron Interact. 2001;1(4):377-385.

25. Laemmly U. K. Cleavage of structural proteins during the assembly of the head of bacteriophage T4. Nature. 1970;227(5259):2244-2750.

26. Sun X. Y., Shi J., Han L., Su Y., Li Z. G. Anti-histones antibodies in systemic lupus erythematosus: prevalence and frequency in neuropsychiatric lupus. J. Clin. Lab. Anal. 2008;22(6):271-277.
27. Kamalanathan A., Goulvestre C., Weill B., Vijayalakshmi M. Proteolysis activity of IgM antibodies from rheumatoid arthritis patients' sera: evidence of atypical catalytic site. J. Mol. Recognit. 2010;23(4):577-582.

28. Lacroix-Desmazes S., Bayry J., Kaveri S. V., Hayon-Sonsino D., Thorenoor N., Charpentier J., Luyt C. E., Mira J. P., Nagaraja V., Kazatchkine M. D., Dhainaut J. F., Mallet V. O. High levels of catalytic antibodies correlate with favorable outcome in sepsis. Proc. Natl. Acad. Sci. USA. 2005;102(11):4109-4113.

Received 23.01.2014 